\title{
The Politics of Environments before the Environment: Biopolitics in the longue durée
}

L'air est un souverain très puissant qui règne en tout et sur tout.

Il vaut la peine d'en contempler la puissance.

(Hippocrates, De Flatibus, III. 2, translation Jacques Jouanna)

\begin{abstract}
Our understanding of body-world relations is caught in a curious contradiction. On one side, it is well established that many concepts that describe interaction with the outer world'plasticity' or 'metabolism'- or external influences on the body - 'environment' or 'milieu'appeared with rise of modern science. On the other side, although premodern science lacked a unifying term for it, an anxious attentiveness to the power of 'environmental factors' in shaping physical and moral traits held sway in nearly all medical systems before and alongside modern Europe. In this article, I build on a new historiography on the policing of bodies and environments in medieval times and at the urban scale to problematize Foucault's claim about biopolitics as a modern phenomenon born in the European eighteenth-century. I look in particular at the collective usage of ancient medicine and manipulation of the milieu based on humoralist notions of corporeal permeability (Hippocrates, Galen, Ibn Sinā) in the Islamicate and Latin Christendom between the 12th and the 15th century. This longer history has implications also for a richer genealogy of contemporary tropes of plasticity, permeability and environmental determinism beyond usual genealogies that take as a starting point the making of the modern body and EuroAmerican biomedicine.
\end{abstract}

Keywords: biopolitics; environment; Foucault; global history; humoralism; public health; 


\section{Us and Them: On the legitimacy of premoderns}

It is a well-entrenched legacy of Western social theory that something unprecedented happened with the rise of Northern European modernity after the eighteenth century. Whether because of the establishment of unique forms of rationality (Weber), modalities of power (Foucault), or just for its alienation (Marx), anomie (Durkheim), or violence without purpose (Bauman), modernity is seen as something exclusive and special: "a time apart, newly minted, in human history" (Heng, 2011).

While literally the term "modernity", from the Latin modo (just now, recently), indicates a sudden arrival in time, it is probably the German compound Neuzeit (new time or epoch) that more clearly captures the meaning of a radical break in chronology that is usually ascribed to the notion of modernity (Blumenberg, 1985; Koselleck \& Presner, 2002). It is this novel "epochal self-consciousness" (Jay, 2009) that positions us, the Moderns, in a relationship of relative estrangement with regard to the others, either spatial (the colonized) or temporal (the premoderns). As Bruno Latour writes, modernity is thus,

doubly asymmetrical: it designates a break in the regular passage of time, and it designates a combat in which there are victors and vanquished (Latour, 2012, p. 10).

Over the past decades, historians (and anthropologists) have undoubtedly done much to correct this perception of exceptionality of post-eighteenth-century Northern Europe modernity, questioning its uniqueness and exceptionality in demographic trends, science and technology developments, and wider cultural phenomena, including racism (see for instance, Biagioli, 1998; Hart, 1999; Eliav-Feldon, Isaac, and Ziegler, 2009; Heng, 2011 and 2018; 
Goody, 2012; Lehoux, 2012). However, regardless of widening criticisms to sequential, “stage-oriented histories", and teleologies (Davis, 2012, p. 2), unexamined chronologies persist in various social science discourses. In this article I take aim at a particular version of modern exceptionalism, the argument that biopower - after Foucault, the transformation of power from external and repressive to internal and productive, mostly via the mobilization of biomedical knowledge and the manipulation of the milieu - is a development of post eighteenth-century Western modernity. In this article I claim that Foucault's overlooking of a longer history of biopower depends not just on a Eurocentric selection of sources of analysis and timeframe, as many have noted (Stoler, 1995; Mbembe, 2001; Legg, 2007). The “epistemic exclusion" (Go, 2020) I argue, is not just spatial but also temporal in Foucauldian scholarship, that is a blindness to the social dimension of premodern medicine: particularly, the way Hippocratic-Galenic knowledge and practice shaped body/environment configurations (including the civic body) in premodern times. A fine-grained reading of practices and concepts of the environment before modernity is essential to bring to light the deeply biopolitical nature of ancient and medieval medicine. Given the emphasis on corporeal permeability and the power of the environment in premodern medicine, a longer history of governing permeable bodies via manipulation of the milieu enables a richer genealogy of contemporary tropes of plasticity and environmental effects in postgenomics beyond usual histories that take as a starting point the enclosed modern body of Western biomedicine. It illustrates, as we shall see, that our present anxiety to govern biological plasticity is neither unprecedented nor the result of a linear unfolding of scientific growth. A fresh and deossified history of individual and collective technologies of the body porous, or plasticity as a form of life rather than molecular knowledge (Meloni, 2018), displaces our 
ethnocentric confidence in the exceptionality of the present and troubles easily assumed break in the history of individual and social technologies.

\section{Problematizing Foucault's account, chronology and foundations of biopolitics}

It has become canon in the area of STS and social studies of biomedicine to associate biopolitics with a peculiar shift in the nature of power and its relationship to citizens after the European eighteenth century. Foucault originally set the tone by famously defining biopolitics as

the endeavor, begun in the eighteenth century, to rationalize problems presented to governmental practice by the phenomena characteristic of a group of living human beings constituted as a population: health, sanitation, birth rate, longevity, race (2007, p. 1).

The notion of an eighteenth-century break has become well established in sociological and STS literature (Lupton, 1995; Rose, 2001). In a recent article on biopolitics, sociologists Collier and Lakoff sum up the Foucauldian stance on the topic by claiming that:

Whereas classical sovereignty sought to ensure the security of the state itself in the face of foreign and domestic threats, modern biopolitics aims to ensure the health and wellbeing of national populations. Foucault argued that the problem of governing collective life was initially articulated in relation to urban conditions in Europe in the late 18th and early 19th centuries. (2015, p. 25, my italics) 
Although Foucault often expressed caution about sequential models of history (for instance, 2007, p. 8), it is unquestionable that the above summary well reflects Foucault's general point about the birth of biopolitics as a stage-like transition from classical sovereignty (sovereign power over life) to modernity (a regime of power "within the social body, rather than from above it" 1980b, p. 39, my italics). As Foucault wrote in his influential Politics of Health in the Eighteenth century,

Taking a longer perspective, one could say that from the heart of the Middle Ages power traditionally exercised two great functions, that of war and peace (...) To those functions were added - from the end of the Middle Ages - those of the maintenance of order and the organization of the enrichment. Now, in the eighteenth century, we find a further function emerging, that of the disposition of society as a milieu of physical well-being, health, and optimal longevity. (1976[1980a], p. 92).

Albeit often related mostly to the emergence of the biological concept of population, it is evident from the two citations above that the notion of milieu (urban and beyond) is also key to understand the novel politics of health that Foucault identifies with the eighteenth-century break. As much as the concept of population questions of spatiality, environment and their policing are hence at the root of biopolitics. It is probably little known that it was during three conferences in Rio in 1974, that Foucault first introduced the term biopolitics (still in a hyphenated and adjectival form: "bio-political reality" and "bio-political strategy"). In these talks, Foucault described at length the organized public health concerns of the "great" or emerging “modern” nation-states (1994: III, pp. 211-212), such as France, England, Prussia, 
Germany, and Austria, since the eighteenth century. The eighteenth-century German medical police (building heavily on US historian George Rosen, 2015 [1958]), French "urban medicine", and the English work health model (ibid., pp. 210 and ff.) represent here the three legs of Foucault's biopolitical tripod. In each case, the policing and manipulation of the environment is key to explaining the novelty of biopower and the shift of medicine from being "essentially clinical to being social" (1994, Vol. III, pp. 212, 23). This shift (or intensification) is well represented by the emergence of a novel field of enquiry and intervention: no longer or not just aiming at "ill people" but a new mode that is instead "concerned with modes of life, food, dwelling and environment" (cfr. Elden, 2003). The "appearance of a medical field of intervention distinct from diseases" which is "neither therapeutic nor even medical in the strict sense" medicalizes the natural and built environment: "air, water, construction, terrains, sewerage" becomes now a new "object of medicine", Foucault claims. The first hydrographic plan in Paris (1742) is cited here as evidence of this break. In other writings, Foucault presents a similar chronology, for instance for architecture. In his conversation on "The Eye of Power" (1978b), he claims that:

Architecture begins at the end of the eighteenth century to become involved in problems of population, health and the urban question. Previously, the art of building corresponded to the need to make power, divinity and might manifest (1978b, p. 148).

Similarly, for the medicalization of the city. In The politics of health in the eighteenth century (second version, 2014) Foucault writes, 
In the eighteenth century, the pathogenic city (....) called forth a medical discourse on urban morbidity and a medical surveillance of a whole series of arrangements, buildings, and institutions (2014, p. 120).

Citing J. P. L. Morel's Dissertation on children disease in Lille, France (1812) as evidence for this shift, Foucault claims that an intensified medical power was now required to police:

the urban space in general-for it constituted perhaps the most dangerous milieu for the population. The location of different districts, their dampness and exposure, the ventilation of the entire city, its water and sewer systems, the location of cemeteries and slaughterhouses, the population density — all these constituted factors that play a decisive role in determining the mortality and morbidity of residents. The city, with its principle spatial variables, appeared as an object to medicalize (Foucault, 2014, p. 121, my italics)

The above passage is particularly interesting not only because it shows how the manipulation of the milieu is key in the definition of biopolitics, but also because to make sense of its underlying chronology, a clear demarcation has to be established between the old and the new, post-eighteenth-century medicine. Perfectly aware that a medical problematization of food, environment, and modes of life dates back, in the West, to the Hippocratic corpus (fifth century BCE), Foucault claims that 
The old notion of a regime understood as both a rule to live by and a form of preventative medicine tended [in the eighteenth century] to expand and to become the collective "regime" of a population taken as a whole. (2014, p. 120, my italics)

There were "exceptions" before, Foucault says:

the regulations to be applied in times of epidemics, the measures that were taken in infected cities, the quarantines that were imposed in certain large ports;

but beyond these limited cases of socialized and authoritarian medical intervention: medicine understood and exercised as a 'service' was never anything but one element of 'relief' (ibid., p. 115).

A decade later, when describing technologies of life in the Classical Antiquity $(1985,1990)$, Foucault did not abandon this key point. In Greece and Rome, medical knowledge produced a rich spectrum of technologies of the self, but this knowledge stayed to political intervention in an analogical not a direct relationship: good rulers must know how to govern themselves following medical regimens, but medicine is not taken up directly in the management of the milieu, planning of the city or care for the health and security of a population. It is this argument, which is central to the claim of a modern novelty of biopolitics as unprecedented assemblage of population's vitality and management of its surroundings, that I will challenge in the second part of this article, after pausing to reflect on some preliminary

\section{Of Names and Things: On the Limits of Foucauldian nominalism}

Although in other areas - the history of prison, social control, and the military, for example a new generation of scholars has challenged the empirical foundations and chronology of Foucault's accounts (Geltner, 2014; Powel, 2017; see also Spierenburg, 2004), the argument 
for an exclusive modernity of biopower has remained fundamentally unscrutinised, particularly among social scientists. This, although Foucault's announcement of a modern biopolitical break was admittedly provisional and exploratory: "vaguely" defined, as he frankly recognizes $(2007$, p.1). It is important to remember that no single book-length treatment (in spite of one titled The Birth of Biopolitics: 2008), nor complete papers (with the exception perhaps of the Politics of health in the eighteenth century), went beyond a number of working hypotheses, albeit often stated with epochal words - the “entry of life into history”, "the biological threshold of modernity “ (1978a, pp. 141142).

However, the reasons for the uncritical acceptance of Foucault's chronology go beyond the lack of interest in premodern environmental or urban history among social scientists or the seductive allure of Foucault's oracular claims. There are two methodological problems that make the coincidence of modernity (or liberalism or the Enlightenment) and biopower so obvious as to appear unproblematic in Foucault and Foucauldian scholarship. Neither of these methodological problems are untreatable, in the sense that it is possible to disentangle the notion of biopolitics from modern forms of power and rationality opening it up to a longer history of environmental governmentality and biopower. However, both need to be addressed explicitly to expand a Foucauldian framework -as I aim at with this article - toward a longer historical perspective. The first methodological issue to be reminded of is Foucault's choice of scale of historical analysis, his prevailing focus on what he calls the "governmentalization" of state functions (2007). It is true that the governmentality framework aims to pluralize power into a network of different sources across society (Rose and Miller, 1992), but there is no doubt that 
in making biopolitics the brainchild of the administrative work of great Northern European monarchies, Austria, Germany, France Prussia, England, Foucault preselected a clear timeframe, world region, and type of political rationality. This narrow selection of sources has not favoured wider and more granular analyses of "graduated" forms of sovereignty (Lemke, 2007) scattered in network-like types government, for instance in premodern trading empires or ancient and medieval cities (Geltner, 2013; Ong, 2005). In particular, the emphasis on cities rather than modern nation-states as an alternative scale for biopolitical investigation is here particularly important. Biopolitics, after all, in its Greek etymology goes back to two main semantic areas: qualified life (bios) and the polis, the Greek term for city from which the Western notion of politics develops. Whereas Greek poleis are quite a specific form of political organization, the city is not. In their multiple emergences and forms - the first cities appeared ca. six thousand years ago in areas as different as Mesopotamia, the Nile River valley, China, and the Mediterranean region, and later the Indus Valley, Mesoamerica and sub-Saharan Africa - cities and towns are a widespread technology of settlement and manipulation of the environment that bring together humans in their plurality to manage their vital forces, symbolic norms, and activities (Clark, 2013; Benjamin and Reinmuth, in press). It is important to note that the connection between the urban milieu, surveillance of spatiality, and biopolitical practices was noted several times by Foucault (1994, p. 734; 2007, p. 337) but always in the context of the modern northern European city, that is cities that belonged to wider nation-state administrative bureaucracies. The ancient city is cited by Foucault as an example of the fundamental freedom of its citizens from the normalizing framework of modern power (2005, p. 447). The pre-eighteenth city for its exclusionary practices (1977, chapter 3: Panopticism). 
The second issue is more substantial and has to do with Foucault's historical nominalism (Veyne, 2008, particularly chapter three). By highlighting the world-making power of names - 'naming things makes them real' - nominalism has had a beneficial function in undermining the illusion of stable and timeless epistemic objects across history. However, its emphasis on the entanglement of specific vocabularies and experience has led not just to forms of incommensurability between cultures, but also - in the case of Foucault - to an insulation of the experience of modernity from other epochs. Since for a nominalist there are no universals only the emergence of specific terms and concepts at certain epistemic thresholds gives access to a "structure of intelligibility" (Foucault, 1989, p. 18). Hence for instance there can be no politics of population before the concept was discovered and hence turned into an object of power/knowledge in the eighteenth century. Similarly, no politics of life itself before life in its abstracted generality, as a species phenomenon, emerged around 1800 (see Lemke et al, 2011, pp. 144 and ff.). As Foucault writes,

One of the great innovations in the techniques of power in the eighteenth century was the emergence of "population" as an economic and political problem: population as wealth, population as manpower or labor capacity, population balanced between its own growth and the resources it commanded. Governments perceived that they were not dealing simply with subjects, or even with "people," but with a "population," with its specific phenomena and its peculiar variables: birth and death rates, life expectancy, fertility, state of health, frequency of illnesses, patterns of diet and habitation (1978a, p. 25)

Similarly, following Foucault's Archaeology of Knowledge, Ian Hacking writes, that Life, labor, and language are not eternal objects of thought but arise as self-conscious topics only at the end of eighteenth century (....) Life became not only an object of 
thought but an object of power: it was not merely individual living persons who might be subjected to the orders of the sovereign (Hacking, 2015, p. 65, my italics)

It is surprising, given the anti-humanistic stance of Foucault's post-structuralism, that both Foucault and Hacking rely here on agential terms like perception and self-consciousness (of population problems) to demarcate the uniqueness of post- eighteenth century demographic politics. These claims, including Hacking's statement that "the census became a hallmark of the enlightenment" (2015, p. 75), obscure practices of population's estimation (meaning of the Latin cènsus, from cēnseō to tax, assess, estimate, also in a moral sense) in the premodern world, from China to the Mediterranean area. Rome for instance, as with many military empires, was obsessed with issues of demography, male-female ratio, fertility and reproduction (Scheidel et al., 2007). Roman authorities promoted not just several census records for taxation purposes, but also self-conscious pro-natalist policies that favoured families with many children and excluded bachelors from inheritance (Ojakangas, 2016, p. 120). Indeed, one major traumatic 'demographic' event is at the very core of Rome's symbolic foundation, the legendary Sabinian rape (raptio: mass abduction of hundreds of women from neighbourhood populations) described by Livy in his Ab Urbe Condita as a way to correct the male-female imbalance in the warrior and hence prevailing male state-power that was Rome (Liv 3.9). Imperial China is another example of a significant contribution to census and data collection in the premodern world. Challenging the Orientalist stereotype of incompetence and backwardness of Chinese bureaucracy, economic historians have reexamined the sophistication and accuracy of Chinese data-collection techniques that over two thousand years drew on complex and plural demographic sources including dynastic histories and local gazetteers (Deng, 2003). For medieval Latin Christendom, Peter Biller's ground- 
breaking book (2000) on demographic thought between 1100 and the 1340s has convincingly argued for the ubiquitous presence of population (multitudo) anxieties in political, medical, theological and legal writings. Debates about chastity, fertility and birth-rates happened in the context of the extension of church control over marriage and sexuality, particularly through the emergence of new orders like the Dominicans and Franciscans. In the wake of the Crusades, specific fears of being outnumbered by Saracens with their overt polygamic policy and perceived religious duty to generate large numbers pushed scholastic intellectuals to discuss the notion of multitudo and its regularities. Influenced by newly translated medical and natural philosophy treatises from the Greek and the Arabic, theologians like Paris bishop William of Auvergne (1190-1249) addressed in their work marriage's rate, sex ratio, population density, fertility and generative span, birth control (vitatio prolis), and other demographic issues (Biller, 2000, pp. 84 and ff.). The 1427 Tuscan catasto (land registry) is also an excellent example of a pre-Enlightenment population data collection, $a$ will to knowledge "in which individuals, organizations, and governments were beginning to record information in numerical form and to use official statistics systematically" (Emigh 2002, p. 663). Its novelty was the vast participation 'from below' of a largely literate (or at least exposed to numeracy) population of artisans and salaried laborers (Brucker, 1993), an important case study that has opened the way for a recent shift beyond top-down and statedriven (and hence only modern) perspectives in the history of data recording (Emigh, Riley, and Ahmed, 2016). Again, this is not to deny specificity to the modern episteme, for instance the rise of a quantitative natural philosophy that since the seventeenth century replaced the qualitative view of matter shaped by Aristotelianism and hence crucially influenced practices of modern governmentality. This is, however, to suggest a methodological disjunction between modern forms of rationality and political concerns for the care of population. 
Quomodo curandum est de multitudine ("How one takes concerned thought about the multitude") as we can read in an early fourteenth-century comment on Aristotle's Politics (Biller, 2000, p.17), is far from being only a post-Enlightenment preoccupation, arising from some abrupt change that denies plurality of experiences over the longue durée. Similar criticism about modernity as the sudden appearance or teleological culmination of some inherent rationality have been raised in parallel contexts for institutional care, the intensification of disciplinary practices, or even more broadly racism (Horden and Smith, 1998; Spierenburg, 2004; Rawcliffe, 2013, pp. 97-115; Heng, 2018). A related story, possibly an even richer one, can be told for the government of the environment and the policing of the social body in the premodern city shaped by Hippocratic and Galenic views of disease as environmentally triggered.

\section{Environments before the Environment}

Our scholarly understanding of body-environment relations is caught in a curious contradiction. On one side, it is well established that many concepts that describe interaction with the outer world - 'plasticity' or 'metabolism'- or external influences on the body 'environment' or 'milieu' - appeared with the rise of modern science. For instance, 'environment' - to designate 'the whole of the surroundings necessary to the existence of the organism" - appeared in English only in 1853 through the translation (by sociologist Harriet Martineau) of the word milieu in Comte's 1830 Cours de philosophie positive (Pearce, 2010). ${ }^{\text {ii }}$ The modernity of the term 'milieu' is also not disputed. Originally employed in physics by Newton and the Newtonians, milieu, as Foucault notes, only since Lamarck really begins to express: 
a set of natural givens - rivers, marshes, hills - and a set of artificial givens - an agglomeration of individuals, of houses, etcetera. The milieu is a certain number of combined, overall effects bearing on all who live in it. It is an element in which a circular link is produced between effects and causes, since an effect from one point of view will be a cause from another. $(2007$, p. 57$)$

According to Foucault, the emergence of milieu as what is needed to act "at a distance of one body on another" (ibid., p. 20) is not just conceptual, however. Given the nominalistic attribution of world-making power to emerging concepts, the discovery of the milieu implies the appearance of a new

field of intervention in which, instead of affecting individuals as a set of legal subjects capable of voluntary actions - which would be the case of sovereignty - and instead of affecting them as a multiplicity of organisms, of bodies capable of performances, and of required performances - as in discipline - one tries to affect, precisely, a population (ibid., p. 21).

The concomitant "discovery" of population and milieu confirms the uniqueness of the modern experience of biopolitics sealing it off from previous epochs ${ }^{\mathrm{iii}}$.

However, if we know that milieu is a benchmark of modernity, we also know from other canonical histories that, although they lacked a unifying term for it (Altmann, 2005; Miglietti and Morgan, 2017), an anxious attentiveness to the power of environmental factors held sway in nearly all medical systems before and alongside modern Europe (Zimmermann 1988; Leslie, 1998; Kuriyama, 1999; García-Ballester et al., 2002; Horden and Hsu, 2013). Airs, waters, and places (as in the Hippocratic Peri aerōn, hydatōn, topōn) but also stars, changing seasons and seasons out of kilter, latitude, rainfalls, landscapes, marshes, noxious smells and scary images all have been at different levels seen as a potential threat to individual and 
collective vitality (see for instance for smell: Rawcliffe, 2008; for eyes/ocular intromission: Hawkins, 2014). The ancient doctrine of the six non-naturals, an umbrella term varying from author to author in Graeco-Roman and Arabic medicine covering factors as different as food, sleep, rest, exercise, passions and emotions, well represent the complexity and intricacies of 'environmental variables' that often in combination one with the other (for instance food with changing seasons or time of the day or age) had to be taken care of to avoid dangerous imbalance. The point here is not to cover under a naïve universalism of the 'environment', cosmological, cultural, and historical differences between Chinese, Greek, Ayurvedic and later Unani medicine - for instance, the 'weather' in Chinese and Galenic medicine is not the same, as Kuriyama has pointed out (2000). The point, however, is to try to access at the phenomenological level, a certain experience of the environment as both curative and threatening, deeply beneficial and a dangerous intruder - and hence of the body as permeable and vulnerable - as it crosses different medical systems. Comments by Hippocrates on "miasmas hostile to human nature" (On Breaths, V. 9) or the air possessing a "diseased excrement" during epidemics or by Roman authors of the first century BCE on the insalubrity of marshy places as full of "invisibly small” animals which "cause serious diseases by invading the body through the mouth or the nose" (Terentius Varro) can be compared to a similar war-like language in traditional Chinese medicine where patients are "wounded" by cold, "hit" by wind or the vital breath is "harmed by polluted breath" in the way that "bandits dare to enter (...) when the walls and barriers [of a fortress] are not solid" (cited in Kuriyama, 2000, pp. 11 and ff; see Epler, 1988). A full perception of the extent of this war between bodies and environments is still obfuscated by a shallow terminology of complexion and physiological imbalance that fails to convey the extent to which this balance is fully responsive to environmental disturbances and hence requires a constant work of protection or 
counter-attack: "The humoral theory commemorated by our histories", as Kuriyama claims "bears no trace" of such worries (2008, p. 424) The premodern body, if we can for once indulge such simplification, is one living in a state of environmental siege and hence constant apprehension: one where taking hot baths at the time of pestilence is dangerous because the relaxing of pores would facilitate the intrusion of infection via polluted air; one where it is discouraged to mount an animal with open sores; one where there is concern about the impact of a menstruating woman on her sexual partner; one in which a non-digested meal can disturb the formation of semen (as a distillation or concoction of that meal) and hence produce monstrous creatures; one in which the image of a leper can be the source of infection, or a scary sight impress a pregnant woman (Meloni, 2019, chapter 2; Kuriyama, 2000; Laqueur, 2002).

Thus, the dilemma of an exclusive modernity of biopower is: how did whole civilizations that believed that corrupt air and noxious smell would not just consume the body but destroy moral faculties (Polybius) take no action at the collective level to protect a body so permeable to be invaded (through the nose, open eyes, or pores)? Why a strong belief in environmental influences of disease including plague did not lead to a systematic attempt to manipulate the milieu - something that according to Foucault and mainstream public health histories only occurred since the eighteenth century?

A number of answers to these questions have been given: that health has become a social imperative only since the Enlightenment, whereas previously what mattered was godliness, purity, and other systems of taboos (Lupton, 1995); that doctors didn't have the authority or credibility to impose health measures at the collective levels (Nutton, 2000); that views of sickness as physiological imbalance necessarily focused on the individual and concrete case, whereas the ontological conception of disease enabled population-level intervention 
To be published in Studies in History and Philosophy of Science (2021), Special Issue, "What counts as environment in biology and medicine: Historical, philosophical and sociological perspectives", Edited by Jan Baedke, Tatjana Buklijas. Pls refer and cite from final version

(Hacking, 1996; Rose, 2001); that it is only with modernity that states could really see into the details of people's lives and hence exert power and minute control over them (Scott, 1998). All these answers are sensible and have their raison d'être but they ultimately elide the social worries and deep political nature of a permeable ontology of the body, individual and collective.

Foucault's explanation is, as I have argued above, similar but insists on the individual significance of premodern medicine: the old regimen that regulated individual lives lacked that socialized and political character that medicine took on only since the eighteenth century expanding to "become the collective 'regime' of a population taken as a whole" (2014, p. 120). As Foucauldian sociologists Petersen and Lupton summarize the point:

While medical knowledge was concerned with individual health, the emergence of a biopolitical collective enterprise of public health during the nineteenth century encompassed broad categories of the population and environment, including regulation of psychological, social and physical spheres of life (Petersen \& Lupton, 1996, p. ix).

While there is obviously a peculiarity of technologies of power and forms of expertise that came to prominence since the eighteenth and nineteenth century, it is not correct to claim that Hippocratic-Galenic did not produce its own biopolitical technologies aimed at the collective body. For instance, archaeological evidence has confirmed that the location (distance from humid areas) and design (favouring ventilation) of harbours, military fortifications, monasteries, and mines confirm a Hippocratic-Galenic understanding of disease as triggered by miasmatic factors and marshy areas (Coomans and Geltner, 2013; Geltner 2019b). In his On Architecture (20 BCE ca), Vitruvius demands the architect to be well versed in medical knowledge and suggests various techniques (including slaughtering animals in a certain area) 
to test the quality of the soil before establishing a new city or fortification. When setting out the plan of a city, Vitruvius famously writes:

The choice of a healthy situation (electio loci saluberrimi) is of the first importance. It should be on high ground, in neither a foggy nor rainy region; its aspects should be neither hot nor cold, but temperate in both respects. The neighbourhood of a marsh must be avoided, for in such a site the morning air, uniting with the fogs that rise in the neighbourhood, will reach the city with the rising sun; and these fogs and mists, charged with the exhalation of the marsh beasts, will diffuse an unhealthy effluvia over the bodies of the inhabitants, and render the place pestilent (locum pestilentem). (1.4.1; see more widely Meloni, 2021)

Climatological knowledge based on Hippocratic tropes, as well known, inspired protoracialist arguments that classify populations along a West-East axis, replaced by a North South one at the time of Columbus' travel to the Americas (Wey Gómez, 2008; Meloni 2019, chapter 2). The shaping of conduct and the construction of a socially recognized time for health took place around widespread public institutions such as public bathing and thermae, required by Hippocratic knowledge to maintain the vitality of a population, expel the excess of humoral plethora, and offer a cheap cure to the poor (Meloni, 2021; Nicoud, 2016). Ancient military treatises drew significantly on medical knowledge to improve the vitality of soldiers, select between different recruits, and find the best settlement for fortifications: often an empirical test was the health of the inhabitants, the way their complexion appeared reflected the salubriousness (or lack of) the designed military area(Geltner, 2019b). In an important article on the tricks of "biological warfare" in Antiquity, historian Mirko Grmek shows how medical knowledge based on Hippocratic ideas of disease through miasma was used by various military strategists and particularly by the Syracusans who defeated the 
Athenians by attracting them to marshy areas affected by malaria. The decision to keep the Athenians for longer during military negotiations in insalubrious grounds resulted not just an increase in morbidity but a weakness and demoralization of the enemy (Grmek, 1979). Fumigation, purification of the air or specific environments such as stables or kennels through smoke (fumus in Latin), is another collective technology used since Hippocrates which was invariably recommended until the eighteenth century by French, British and Italian doctors (Ramirez, 1994; Blancou, 1995). In a different context, but still shaped by humoralist views, a colonial biopolitics has occurred in the Americas since the sixteenth century with particular focus on the vitality and work capacity of labouring indios (Pezzarossi, 2017). Drawing on Hippocratic-Galenic conceptions of body permeability and climatological influences imported by Spanish conquistadores, laws were explicitly formulated to control the health of the local labouring populations especially when they moved:

across different climates, an unavoidable part of portering due to the diverse topography of the region (Corcoran-Tadd \& Pezzarossi, 2018, p. 98).

Changes in native populations as a consequence of environmental effects had to be suddenly communicated and recorded, alongside births, deaths and morbidity (ibid.).

Similarly, a biopolitics of racial differentiation was reproduced in colonial Mexico following humoralist notions and practices such as using distinct food to maintain racial separation between colonizers and colonized, given the ubiquitous humoralist belief in the influences of diet on racial types (Earle, 2013; Baedke and Delgado 2019). Complex racial (and gender) taxonomies were elaborated by Creole savants and physicians in the colonies drawing from the humoral Hippocratic language of predominance of different temperaments (López Beltrán, 2007; Hasson, 2009). 


\section{A Medieval Biopolitics in Eurasia: 1100-1500 ca.}

All these examples can, however, still be considered as anomalies in a fundamentally nonbiopolitical context. Foucault has often dismissively judged as too fragmentary attempts made in the past to control populations, record disease and support public health intervention: they lacked the systematic nature of what will be achieved only by modern European states (cfr. Foucault, 2014, pp. 114-115). An important challenge to this argument comes from medieval studies. Here a recent body of scholarship has combined archival and archaeological sources to argue, pace Foucault, that the politics of health in the medieval city was capillary, stable, and proactive rather than exclusionary, shaped by medical knowledge, and operationalized through the establishment of a legislative corpus for health and environmental regulation, town doctors, and in some cases, boards of medical experts (Rawcliffe, 2013; Geltner, 2019a).

A medieval challenge to Foucault's biopolitical "threshold of modernity" (1978a) assumes a particular importance here at two levels. Firstly, it questions a number of self-serving myths by which a European unique sense of modernity was constructed by the representation of a dark Middle Ages based on superstition, stagnation of knowledge and only exclusionary medical intervention, a nineteenth century historical construction that is still evident in several of Foucault's simplistic readings of medieval policy of health as just modelled after quarantine (Foucault 1994, pp. 119 and ff.). As medievalists have recently claimed

The Middle Ages (...) is in fact a colonial category, developed mainly in the eighteenth and nineteenth centuries as (primarily Western) Europeans worked to legitimize, classify, and make sense of colonial policies, practices, and encounters, at the same time that newly forming academic disciplines took up and institutionalised the study of 
religion, the states system, other cultures (...) and began codifying their histories

(Davis 2019, p. 4)

Whether it is the lack of interest in public health or the body, the chaos and dirtiness of its cities or markets, its superstition or backwardness, modernistic views of the Middle Ages have repeated a pattern of exoticization, nativization, barbarism, and denial of agency that perfectly resonates with colonial thinking and intertwines with the Orientalist framework described by Said (1979: Dagenais and Greer, 2000; Davis and Altschul, 2009).

Rosen, the public health historian cited by Foucault as his source for German medical police, lauds the heroic quarantine efforts of medieval times, all the more impressive he writes as they were undertaken in a world in which superstition was rampant and much of the scientific knowledge required for the effective handling of health problems was absent (2015 [1958], p. 36).

Foucault unfortunately did not escape some of these convenient simplifications. A case in point is the way in which he portrays the early Middle Ages through the figure of the leper, separated from the community to maintain the purity of the latter. Historian Carole Rawcliffe (2006), among others (for France see Touati, 1998), has exposed the myth about the rejected and banished leper in medieval times as a simplified construction of Victorian historiography rather than a factual reality corresponding to the nuanced and complex ways in which medieval citizens and institutions responded to leprosy. Moreover, Foucault often suggested that the experience of the plague was the moment that pushed medieval cities to intervene in terms of emergency measures (2014, pp. 112 and ff.). Certainly, in some cases, the bubonic plague worked as a catalyst for strengthening health measures. However, several of these measures and urban statutes of preventive health did predate - by several decades - the Black 
Death (1346-1353) showing the fundamentally proactive nature of the premodern healthscape $(\text { Geltner, 2020) })^{\mathrm{iv}}$.

Secondly, a focus on the Global Middle Ages (Heng, 2014; Holmes \& Standen, 2018) across the Islamicate and Latin Christendom between the eleventh and the fourteenth century moves frame of analysis from the Industrial Revolution and the consolidation of European nationstates to the global history of cities and premodern trading empires. It is important here to consider that, besides a certain provincialism in the selection of sources, one of Foucault's key argument for an eighteenth-century break is demographic, what he calls the "great eighteenth-century demographic upswing in Western Europe" (Foucault 1980[1976], p. 171). Foucauldians have claimed that this gives a strong justification to the exceptionality of eighteenth-century selected by Foucault as "context for the emergence of modern forms of management, discipline and government" (Turner 1997, p. XV). But how unique or exceptional is the eighteenth-century demographic transition in shaping systems of government? Historians have noted that the demographic and urban patterns of growth during the Industrial Revolution also occurred in medieval times, before its downsizing with the Black Death. The history of global demography and urbanization is not progressive or linear, but one of expansion and contraction punctuated by moments of intense growth, scientific and technological efflorescences (Goldstone, 2002; Campbell, 2013). One of such moments occurred between the $11^{\text {th }}$ and 13 th century when $90 \%$ of current cities in Europe were founded and the ratio of urban populations reached $10 \%$ of the total population, a peak that was not exceeded well into the nineteenth century (Geltner, 2019a). In that period, the urban milieu mushroomed in Eurasia across different political and religious contexts. This included the growth of big cities such as Baghdad (with a population between six hundred thousand and two million in the eleventh century), Damascus, Hangzhou, Cordoba, Aleppo, Kairouan, 
Cairo, Toledo, Paris or Venice. Importantly, this time of urban growth and subsequent demographic, environmental and organizational pressure is also a time of cross-fertilization and synthesis of medical knowledge mostly via the work of polymaths such as Ibn Sina who brought together Persian, Arabic, Greek and Indian sources (Goodman, 2006). Since the late twelfth century, several medical works were translated in Southern Europe into Latin (including Ibn Sīnā's Canon, by Gerard of Cremona, completed in 1187 and other major Arabic medical works by Constantine the African), Hebrew, and vernaculars, in princely courts, monasteries and later in universities and represented the platform upon which 'European' medicine flourished after the thirteenth century. However the so-called rebirth of learned medicine in Europe, from the transregional perspective that today is called the Global Middle Ages (Heng, 2014; Holmes \& Standen, 2018) is more accurately described as the “catching up" of Latin West with an already well established network of environmental medicine and culture of health that was firmly established across Eurasia, and particularly active across the Silk Road (Milward, 2013). This medical knowledge was more than academic or learned but a social culture of health (see Gari, 2002). Ubiquitous references to medical substances, personal hygiene, baths, perfumes, spices, methods of preparation of potions and pills have been found in the documents of the Jewish community of Genizah in Old Cairo particularly in the period between the tenth and the thirteenth century (Goitein, 1993; Lev and Amar, 2008, p. 11). A century later, in medieval cities, medical knowledge deeply penetrated political views about the health or decline of the civic body shaping several organicist metaphors of the market as the city's stomach and the river as its arteries (Rawcliffe, 2013). Since the thirteenth and fourteenth century, tropes about bodily humours (Arabic: akhlat) were widespread among philosophers and political and legal scholars from the Islamicate World to Florence, from Persia to the Ottoman Empire to describe the 
functioning of social organization and portray rulers as skilled physicians (Syros, 2013). Not only the concept of "regimen" (Latin for rule or government) had an obvious political origin and could be found interchangeably in health books (regimen sanitatis) as well political treatises (De regimine principum: on the Government of Rulers; De regimine civitatis: on the Government of the City; De regimine politiae: On the Government of a Polity: Weeda and Rawcliffe, 2019). More broadly, key humoralist notions like "balance" (aequalitas in Latin) and "complexio" were further transferred into wider politico-theological debates on the health of the urban body as a result of a complex equilibrium or equalization among parts. It has been well documented for instance that Galen's medical work (2nd CE) and peculiar understanding of the body as a system in dynamic equalization did impact medieval economic and political thought particularly Marsilius of Padua's Defensor Pacis (1324) and Nicolas Oresme's De Moneta (1355). (Kaye, 2014).

\subsection{Policing Morals and the Environment in Medieval Cities}

If the notion of humoral balance and medical regimen was political well before what Foucault claims, this knowledge was more than literary or metaphorical. It did inform proactive public intervention and sanitary legislation that aimed at protecting the populations' health and regulating the complex metabolism between cities and their surroundings. Whether it is in the Islamicate or the later Ottoman Empire, Medieval English towns or cities in France the Lowlands, the Italian peninsula or Adriatic towns in what is today Croatia (Leguay, 1999, 2002; Vanzan Marchini, 2000; Geltner, 2012; Rawcliffe, 2013; Grmek, 1980; Petaros et al., 2013; Blažina-Tomić and Blažina, 2015; Skelton, 2015 for a later period), historians have brought to light a longer tradition of preventive measures that since the early thirteenth 
century operated "for the benefit and health of all" showing a significant level of concern for the natural and the built environment (Geltner, 2019a for a rich overview).

As historians Claire Weeda and Carole Rawcliffe recently write:

from the twelfth century onward, authorities promptly responded with a plethora of regulations to facilitate, at least in theory, the orderly cohabitation of dwellers within the city walls. Many of these rules concerned public health matters, such as the disposal of waste, the protection of water supplies, and the sale of wholesome foodstuffs. In some cases, sanitary regulations drew from Ancient Greek and especially Galenic medical theory, which stressed the importance of a hygienic environment in safeguarding the urban body from disease. The effective execution of such measures relied in part on the active engagement and compliance of the population. Shared assumptions regarding physical and spiritual well-being, social cohesion, neighbourliness, and economic prosperity, as well as the pursuit of ideals of urbanity, fed into communal efforts to police the environment, the behaviour of others, and the conduct of the self $(2019$, p. 23 , my italics $)$.

It is very important to approach this cluster of political measures and medical knowledge avoiding a positivistic attitude according to which these would be just antecedents, more or less successful, of contemporary measures based on modern biomedicine. Quite the opposite, the point here is to understand the premodern experience of bodies and cities on its own terms (Horden, 2019) that is impartially, as the sociology of scientific knowledge would claim, "with respect to truth and falsity, rationality and irrationality, success or failure" (Bloor, 1991, p. 7). Some measures of course are entirely recognizable to us, whether it is concern over the removal of animal carcasses, fear of contaminated water and wells, or the desire to have human-made environmental hazards - from carpenters or dyers to people 
working with metals for instance - relegated to the edge of the city walls explicitly to fight pollution. However, the rationale behind these measures can be less obvious than it would seem. A decline in the use of bathhouses in Europe has been directly connected to fear of the plague, exactly on the belief that hot vapour would make body pores more relaxed and hence vulnerable to an epidemic (Ashenburg, 2011, pp. 91 and ff.). In this miasmatic battle for health, particular importance was given to flowers, garlands, and other aromatic herbs (some of which filled the typical bird-like beak mask of the plague doctor) as prophylactic means with which to fight the foul odour of corrupted air as a potential source of disease (Classen et al.1994, p. 61). Burning pit or wood, wearing perfumed jewels or using a sponge soaked in vinegar were also techniques frequently used to fight miasma. Whatever we may think of these measures, the Galenic experience of the body is one not of apathy of health-fatalism but of constant anxiety and vigilance (Cipolla, 2004; Geltner, 2019). Medical humoralism for centuries informed people's behaviour, the location (distant from humid areas) and design (favouring ventilation) of harbours, military fortifications, bathhouses and mines (Coomans and Geltner, 2013).

In a passage that obviously shows the influence of miasmatic view of disease the influential Persian scientist and philosopher al-Razi (865-925) recommends that military fortifications should be pitched in summer on hills and high places, tents being directed towards the north wind, with plenty of air space between tents. Animals should be kept as far from the tents as possible. In winter the camps should be placed in low-lying places, preferably at the foot of hills or mountains, tents being directed towards the east or south, alternate pairs of tents being joined together. When moist south winds blow, rations should be cut down, wine should be interdicted, and more military exercises taken. When the air is dry, just the opposite regime should be enforced. Sick cattle 
should be kept far from the camp, in low windless places. Poisonous odorous plants and trees should be burned or the camp site should be above them. Food and drink, as causing many diseases, should be inspected with great caution. (cited in Geltner 2019b, p. 55)

Humoralism shaped food tradition (given the deep connection between food, climate, and humoral balance), provoked intense fears and suggested actions in response to beliefs of dangerous "environmental" influences. If bad smells coming from roads, wells or animal blood, were not just disgusting but a potential cause of disease, it is not surprising that organized responses to this problem arose in the premodern world. As documented by historians of medieval Europe and the Islamicate, programs and schemes were established for fighting urban pollution, maintaining and repairing water conduits, finding designated areas for contaminated waters or fumes, controlling the sale of food and regulating waste from diseased meat and discarding blood in urban markets, policing the activities of and forcing medieval craft and trade associations (guilds) to give access to public inspectors for the control of their premises and merchandise. Numerous fines and court orders were issued against violations, risky professional categories, and negligent householders or neighbours. Multiple documents demonstrate the proactive interest of citizens and local elites to have these measures implemented in defence of "civic pride", decorum or the safety of the city (McVaugh 2002; Geltner, 2012, 2013 and 2019; Roberts, 2019; Weeda and Rawcliffe, 2019). Specific categories were particularly targeted (butchers, barber-surgeons, brewers, taverners, leather artisans, smiths) and so were laundresses, day-labourers and domestic cleaners (Geltner, 2013). 
Consistent environmental intervention was put in place well before the Black Death, environmental historian John Aberth writes

In 1307 England forbade burning of sea coal in limekilns as a result of complaints about coal fumes made in 1285 and 1288, and in 1310 London appointed a "Conduit Keeper" to preside over the city's water supply. On the Continent, Marseilles in 1253 ensured water from the river Jaret, diverted to irrigate gardens and supply tanners, did not flow back into the harbor; and Florence, beginning in 1322, regulated against piscicides used for fishing in the Arno, and in 1330 Barcelona controlled stenches said to be issuing from drains, sewers, and latrines built in the Jewish quarter (2013, p. 66) Specific public officials and experts were appointed from the Islamicate to Europe "for the preservation of people's health" (Geltner, 2020). These included in the Italian peninsula figures such as road officials (viarii), building managers (magistri hedificiorum), and mud or dirt masters (fango officials) appointed to maintain the cleanliness and accessibility of urban infrastructures. Interestingly, for a more-than-European history of biopolitics, one of the earliest figures to supervise public life is, since the ninth century, the Islamic market inspector, the muhtasib (Buckley, 1992).

The muhtasib is one of the first examples of a pastoralization of the public sphere given the authority he was given over the control of public behaviours in relation to preventing frauds with food, weights, scales or managing building codes and taking care of urban pollution (Buckley, 1992, p. 99; 1999; Agresta, 2018 for Valencia). Unlike the Orientalist view of chaotic Islamic $s \bar{u} q s$, the power of the muhtasib to enforce rules in the market is a clear example of their structured nature (Valérian, 2013). The muhtasib's role was both religious and secular, aimed to support the caliph's task "to command good and forbid evil" (Glick, 1971; Geltner, 2019). Its authority sometimes expanded to the control of slave 
markets, currency or, like the road officials in Italy, ensuring that highways were cleared (Buckley, 1992). The muhtasib became a model for similar forms of intervention elsewhere. Replica of the muhtasib can be found in the Iberian Peninsula well after the end of the Islamic dominion.

This role appeared with the name of mustacaf in Valencia, mostassaf in the Crown of Aragon, almuhtasáb in Andalusia, almotacén or almotace in Portugal, and as a veedor (from the Spanish veer, watch or inspector) de carreras in fourteenth-century Saragossa (McVaugh, 2002; Geltner, 2019 chapter 5). In the thirteenth-century Italian peninsula, there is no muhtasib but the institution of local proto-police forces that largely predates Foucault's arguments about the eighteenth century and shows how medieval cities where important sites of experimentation for biopolitical practice and a longer history of governmentality (Geltner, 2019a). In the case of Bologna's Office of "Crowns and Arms" (thirteenth century), policelike forces aimed at law enforcement did not have just repressive functions, but sought to promote "the health, productivity, and general well-being of the community", by appealing to the common good (bonum commune or utilitas publica), or alternatively to the good state (bonum statum) or good governance (bonum regimen) (ibid. 7-8) (Roberts, 2019, p. 7). Albeit Bologna's quantitative presence of berrovarii or berrovieri (patrolling forces) was relatively limited for a population of ca. fifteen thousand, other Italian cities, like Venice and Siena, had by modern standards a higher ratio of patrolling forces to inhabitants compared to contemporary standards (Ibid., p. 24). While there is a plurality of terms for what we would call after the eighteenth century 'police', it is difficult to deny that in several medieval republics these urban security forces were established to protect the welfare of the community, including the physical and moral environment of the city. 
Moving to the Eastern Mediterranean, the biopolitical experience of the Ottoman Empire has been richly documented too, beyond simplistic claims of hygienic apathy that are clichés for those areas in the European literature since the Enlightenment.

Historian Nükhet Varlik has described in great cities like Istanbul, since the late fifteenth century, the emergence of a "new public health consciousness" and "new forms of surveillance technologies over bodies" that brought together environmental and health control and moral policing $(2015$, p. 290). The policing of environments (clean air, water) in the capital and major centres like Damascus, Aleppo, Thessaloniki and the holy cities of Medina and Mecca was pursued for both sanitary and moral reasons: health, moral control and governance came together in the biopolitics of the Ottoman administration alongside a careful attention to demographic measures (including forced relocations), and "softer" measures, like the institution of tax registers (late fourteenth century) and the systematic record-keeping of daily mortality to make the effects of "epidemics 'legible' to the Ottoman central administration". Far from being exceptional, this policy found frequent justifications in religious texts where, for instance, the Prophet would remind that in any town a "skilled physician" is required alongside a "wise sovereign" and a "cautious governor".

A similar combination of moral, medical and environmental regulation emerges from the work of Abigail Agresta on environmental sanitation in the city of Valencia (1300-1500). Fascinatingly, Agresta shows how the humoralist anxiety for evacuations and open pores, and hence bloodletting as a key technique, mirrored the local council's concern for stagnant waters as potential source of corrupted matter and hence epidemics. Regulating blockages in the urban sewage system reflected perfectly a humoralist understanding of free flows and evacuations to expel the excess of plethora and humoral imbalance. Agresta's work shows moreover the entangled web of religious, environmental and health interventions for the salut 
of the civic body - combining legal regulations and public religious processions in the streets as a response to drought or floods.

Indeed, medical language and metaphors coexisted well with religious thinking from the Islamicate to Christian Europe and actually gained authority via political and religious arguments and analogies. Regardless of its deeply materialistic roots in Hippocrates or Galen, the language of moderation, regulation of excesses and evacuations of vicious or corrupt humours from the individual or collective body offered plenty of resources for theological reflections or sermons in Christian and Islamic texts. Metaphors of sickness as "falling from the balance of heaven" and filth as "the mother of corruption" (Henderson, 2018) were widespread in homiletic speeches as well as the image of Christ as a well-balanced humoral example (Rawcliffe, 2013). Growing concerns that self-indulgent behaviour would cause health and spiritual damage alike was also pointed out by priests and preachers (Bayless, 2012; Rawcliffe, 2013; Maryan, 2016). Once again, then as now medicine had a social meaning that cannot be narrowed down into an individual practice of the self.

\section{Conclusion. Networks: biopolitics from modern biomedicine to global humoralism}

While it remains true that the literature above reviewed on a medieval biopolitics is still nascent compared to more systematic studies of the modern body, it presents important and fascinating elements for a less parochial history of biopolitics that encompasses different chronologies, cosmologies of life and ontologies of the body. The earlier origins of biopolitics here analyzed focuses on a period where European medicine has no epistemic or technological privilege, but it is actually just one region in a wider network of technological exchanges and scientific translations that, mostly through the Islamicate world, connects the Atlantic, the Mediterranean, the Middle East, and Central Asia (Zimmerman, 1995; Yoeli- 
Tlalim, 2019). Moreover, a number of important similarities (humoral cosmology, notions of imbalance) exist further eastward with Iranian and Indian (Ayurveda) medicine, and a shared emphasis on environmental determinants of health with Chinese medicine (Craik, 2009; Kumar, 2010; Syros, 2013; Horden and Hsu, 2013). The second half of the thirteenth century that Janet Abu-Lughod has identified as start date for the formation an early world-system from China to the Latin West (Abu-Lughod, 1989) was actually already anticipated by several decades by intense exchanges of medical knowledge through key silk road “information entrepôts” such as Byzantium, Baghdad, and Bukhārā (Millward, 2013, p. 54 and ff). This latter was for two decades the city of Ibn Sīnā, whose Canon of Medicine (1025) became the most authoritative medical synthesis for centuries in the Islamicate and Latin Europe (Goodman, 2006). Here, it was translated a century later in Toledo, a city known for its leading school of translation and vibrant coexistence of Islamic, Christian and Jewish traditions also after the Castilian conquest (1085) from the Arabs (Otabek, 2020). An analysis of the transregional traffic of medical humoralism as an "early globality" before European hegemony becomes therefore strategic to reconnect histories and relations (Bhambra, 2007) and understand our present as more than a returning variant of some modern European event (Chakrabarty, 2000). Recent calls to a global turn in history of science and STS (Anderson 2002; Fan, 2012; Raj 2013), alongside seminal contributions to the longue durée of diseases (Grmek, 2018) will benefit from a dialogue with this emerging premodern history of biopolitics and governmentality. This article can be seen as a contribution to a two-way conversation where modern theory - such as Foucault's biopolitics - enriches our readings of premodern sources, and premodern sources challenge and stimulate the foundations and assumptions of modern theories (cfr. Bethencourt, 2013). Given how much tropes of corporeal permeability and power of environmental effects in global humoralism resonate 
with more contemporary views of plasticity of the body, heredity, and race (Zimmermann 1988; Anderson 2014; Rooney 2020), an articulation between premodern, non-Western and contemporary medical sources offers a unique opportunity to illuminate forgotten genealogies and exchange of ideas and practices around the problem of how to live with a porous body at the individual and collective level.

\section{Acknowledgments}

I am very grateful to two anonymous reviewers for their very valuable and constructive feedback to my first iteration, and to the two editors of this Special issue for important suggestions on the finally revision of the text. I thank Jenny Lucy (ADI) for help with language and Galib Bashirov (ADI) for help with references. I have benefited from insightful conversations with Guy Geltner (Amsterdam and Monash) on the new premodern biopolitics literature and its old and often unrecognized sources. All mistakes are obviously just mine. Finally, I gratefully acknowledge funding from an Australian Research Council Future Fellowship (FT180100240).

\section{Bibliography}

Aberth, J. (2013). An Environmental History of the Middle Ages. The Crucible of Nature. London: Routledge

Abu-Lughod, J. (1989). Before European Hegemony: the World System AD 1250-1350. Oxford University Press.

Agresta, A. N. (2016). Many Waters: An Environmental History of Valencia, 1300-1500. Yale University.

Altmann, A. (2005). The Treasure Trove: Judah Halevi's Theory of Climates. Aleph, (5), 215 246.

Anderson, W. (2002). Introduction: Postcolonial Technoscience. Social Studies of Science, $32(5-6), 643-658$ 
To be published in Studies in History and Philosophy of Science (2021), Special Issue, "What counts as environment in biology and medicine: Historical, philosophical and sociological perspectives", Edited by Jan Baedke, Tatjana Buklijas. Pls refer and cite from final version

Anderson, W. (2014). Racial conceptions in the Global South. Isis, 105(4): 782-792.

Ashenburg. K. (2011). Clean: An Unsanitised History of Washing. Profile Books.

Baedke, J., \& Delgado, A. N. (2019). Race and nutrition in the New World: Colonial shadows in the age of epigenetics. Studies in History and Philosophy of Biological and Biomedical Sciences, 76, 101175.

Bayless. M. (2012). Sin and Filth in Medieval Culture: The Devil in the Latrine. Routledge.

Benjamin, A. \& Reinmuth, G. (in press) Territorializing Life: A Note on Biopolitics and Architecture.

Bethencourt, F. (2015). Racisms: from the Crusades to the Twentieth Century. Princeton University Press.

Bhambra. G. K. (2007). Rethinking Modernity: Postcolonialism and the Sociological Imagination. Springer.

Biagioli, M. (1998). The scientific revolution is undead. Configurations, 6(2), 141-148.

Biller, P. (2000). The Measure of Multitude: population in medieval thought. Oxford University Press.

Blancou, J. (1995). History of disinfection from early times until the end of the 18th century. Revue scientifique et technique (International Office of Epizootics), 14(1), 2139.

Blažina-Tomić, Z., \& Blažina, V. (2015). Expelling the Plague: The Health Office and the Implementation of Quarantine in Dubrovnik, 1377-1533 (Vol. 43). McGill-Queen's PressMQUP.

Bloor, D. (1991). Knowledge and Social Imagery. University of Chicago Press.

Blumenberg, H. (1985) The Legitimacy of the Modern Age. Cambridge (Mass): MIT Press

Brucker, G. (1993). Florentine Voices from the" Catasto", 1427-1480. I Tatti Studies in the Italian Renaissance, 5, 11-32.

Buckley, R. (1992). The Muhtasib. Arabica, 39(1), 59-117

Buckley, R. (1999). The Book of the Islamic Market Inspector. Oxford University Press.

Campbell, B. M. (2016). The great transition. Cambridge University Press.

Chakrabarty, D. (2000). Provincializing Europe: Postcolonial Thought and Historical Difference. Princeton University Press. 
Cipolla, C. M. (2004) Public Health and the Medical Profession in the Renaissance. Cambridge University Press.

Clark, P. (Ed). (2013). The Oxford Handbook of Cities in World History. Oxford University Press.

Classen C, Howes, D., \& Synnott, A. (1994). Aroma: The Cultural History of Smell. New York: Taylor \& Francis.

Collier, S. J., \& Lakoff, A. (2015). Vital systems security: Reflexive biopolitics and the government of emergency. Theory, Culture \& Society, 32(2), 19-51.

Conrad, L. I., \& Wujastyk, D. (2017). Contagion: perspectives from pre-modern societies. Taylor \& Francis.

Coomans, J, \& Geltner, G. (2013). On the Street and in the Bathhouse. Anuario de Estudios Medievales, 43(1), 53-82.

Corcoran-Tadd. N., \& Pezzarossi, G. (2018). Between the South Sea and the mountainous ridges: biopolitical assemblages in the Spanish colonial Americas. Post-Medieval Archaeology, 52(1), 84-101.

Craik, E. M. (2009). Hippocratic bodily "channels" and oriental parallels. Medical history, 53(1), 105-116.

Curtis, B. (2002). Foucault on governmentality and population: The impossible discovery. Canadian Journal of Sociology/Cahiers canadiens de sociologie, 505-533.

Dagenais, J., \& Greer, M. R. (2000). Decolonizing the Middle Ages: Introduction. Journal of Medieval and Early Modern Studies, 30(3), 431-448.

Davis, K. (2012). Periodization and sovereignty: How ideas of feudalism and secularization govern the politics of time. University of Pennsylvania Press.

Davis, K. (2019). From periodization to the autoimmune secular state. Griffith Law Review, $1-15$.

Davis, K., \& Altschul, N. (2009). Medievalisms in the Postcolonial World: the Idea of "the Middle Ages" outside Europe. Johns Hopkins University Press.

Deng, K. (2003). Fact or fiction? Re-examination of Chinese premodern population statistics. LSE Working Papers, WP 68, 76/03, pp. 1-84 
To be published in Studies in History and Philosophy of Science (2021), Special Issue, "What counts as environment in biology and medicine: Historical, philosophical and sociological perspectives", Edited by Jan Baedke, Tatjana Buklijas. Pls refer and cite from final version

Earle, R. (2014) The Body of the Conquistador: Food, Race and the Colonial Experience in Spanish America, 1492-1700. Cambridge: Cambridge University Press.

Elden, S. (2003). Plague, panopticon, police. Surveillance \& Society, 1(3), 240-253.

Emigh, R. J. (2002). Numeracy or enumeration? The uses of numbers by states and societies. Social Science History, 26(4), 653-698.

Emigh, R. J., Riley, D., \& Ahmed, P. (2016). Antecedents of censuses from medieval to nation states: How societies and states count. Springer.

Epler Jr, D. C. (1988). The concept of disease in an ancient Chinese medical text, the Discourse on Cold-Damage Disorders (Shang-han Lun). Journal of the history of medicine and allied sciences, 43(1), 8-35.

Eliav-Feldon, M., Isaac, B. H., \& Ziegler, J. (Eds.). (2009). The origins of racism in the West. Cambridge University Press.

Fan, F. T. (2012). The Global Turn in the History of Science. East Asian Science, Technology and Society: An International Journal, 6, 249-258.

Foucault, M. (1977). Discipline and Punish: The Birth of the Prison. New York: Pantheon Books.

Foucault, M. (1978a [1976]). The History of Sexuality: Vol I, An Introduction. London: Allen Lane.

Foucault, M. (1978b) The Eye of Power, Semiotexte 3(2): 6-19, 1978

Foucault, M. (1980a [1976]). The politics of health in the eighteenth century. In C. Gordon (Ed.) Power/Knowledge. Selected Interviews and Other Writings, 1972-1977 (pp.166182). KNOPF US.

Foucault, M. (1980b). Power/Knowledge: Selected Interviews and Other Writings 1972-1977 (edited by Colin Gordon). New York: Pantheon Books.

Foucault, M. (1985). The History of Sexuality, Vol. 2: The Use of Pleasure. New York: Random House.

Foucault, M. (1989). Introduction." In The Normal and the Pathological by Georges Canguilhem. 7-24. New York: Zone Books. 
To be published in Studies in History and Philosophy of Science (2021), Special Issue, "What counts as environment in biology and medicine: Historical, philosophical and sociological perspectives", Edited by Jan Baedke, Tatjana Buklijas. Pls refer and cite from final version

Foucault, M. (1990). The History of Sexuality, Vol. 3: The Care of the Self. London: Penguin Books.

Foucault, M. (1994). Dits et écrits 1954-1988, volume $3^{\text {rd }}$, 1976-1979. In D. Defert, F. Ewald and J. Lagrange (Eds). Paris: Gallimard

Foucault, M. (2004). The crisis of medicine or the crisis of antimedicine? [Translation of the First Brazilian conference: "Crisis de un modelo en la medicina”] Foucault Studies, 519.

Foucault, M. (2005). The Hermeneutics of the Subject. New York: Palgrave Macmillan. Foucault, M. (2007). Security, Territory, Population. New York: Palgrave Macmillan. Foucault, M. (2008). The Birth of Biopolitics. New York: Palgrave Macmillan.

Foucault, M. (2014 [1979]). The politics of health in the eighteenth century. Foucault Studies, 113-127

García-Ballester, L., Arrizabalaga, J., Cabre, M., \& Cifuentes, L. (2002). Galen and Galenism: theory and medical practice from Antiquity to the European Renaissance. Ashgate.

Gari, L. (2002). Arabic treatises on environmental pollution up to the end of the thirteenth century. Environment and History, 475-488.

Geltner, G. (2012) Public Health and the Pre-Modern City: A Research Agenda. History Compass, 10(3), 231-245.

Geltner, G. (2013). Healthscaping a medieval city: Lucca's Curia viarum and the future of public health history. Urban History, 40(3), 395-415.

Geltner, G. (2014). The Medieval Prison: a social history. Princeton University press.

Geltner, G. (2019a). Roads to Health: Infrastructure and Urban Wellbeing in Later Medieval Italy. University of Pennsylvania Press.

Geltner, G. (2019b). In the camp and on the march: Military manuals as sources for studying Premodern Public Health. Medical History, 63(1), 44-60.

Geltner, G. (2020). The Path to Pistoia: Urban Hygiene Before the Black Death. Past \& Present, 246(1), 3-33

Glick, T. (1971). Muhtasib and Mustasaf: A Case Study of Institutional Diffusion. Viator (2) 59-81.

Go, J. (2020). Race, Empire, and Epistemic Exclusion: Or the Structures of Sociological Thought. Sociological Theory 
Goldstone, J. (2002). Efflorescences and economic growth in world history: rethinking the "Rise of the West" and the Industrial Revolution. Journal of World History, 323-389.

Goodman, L. (2006). Avicenna. Ithaca (NY): Cornell University Press.

Goody, J. (2012) The theft of history. Cambridge University Press.

Grmek, M. D. (1979). Les ruses de guerre biologiques dans l'Antiquité. Revue des Études grecques, 92(436/437), 141-163.

Grmek, M. D. (1980). Le concept d'infection dans l'Antiquité et au Moyen Age, les anciennes mesures sociales contre les maladies contagieuses et la fondation de la lère quarantaine à Dubrovnik (1377). RAD Jugoslavenske Akademije Znanosti $i$ Umjetnosti, 384, 9-54.

Grmek, M. D. (2018 [orig. 1969]) "Preliminaries for a Historical Study of Diseases", In Pathological Realities. Fordham University Press, 2018.

Hacking, I. (2015). Biopower and the avalanche of printed numbers. Biopower: Foucault and beyond, V. Cesney and E. Morar (eds.). University of Chicago Press

Hart, R. (1999) "Beyond Science and Civilization: a post-Needham critique." East Asian Science, Technology, and Medicine 16, no. 1, pp. 88-114.

Hasson, O. (2009). On sex-differences and science in Huarte de San Juan's Examination of Men's Wits. Iberoamerica Global, 2(1), 195-212.

Hawkins, J. (2014). Sights for Sore Eyes: Vision and Health in Medieval England. On Light, 137-156.

Henderson, J. (2018). "Filth is the mother of corruption": plague, the poor and the environment in early modern Florence. In Engelmann, L., Henderson, J., \& Lynteris, C. (Eds), Plague and the City. (The Body in the City) (pp. 69-90). London: Routledge.

Heng, G. (2011). The invention of race in the European middle ages I: race studies, modernity, and the middle ages 1. Literature Compass, 8(5), 315-331.

Heng, G. (2014). Early Globalities, and Its Questions, Objectives, and Methods: An Inquiry into the State of Theory and Critique. Exemplaria 26, no. 2-3 (2014): 234-253.

Heng, G. (2018). The invention of race in the European Middle Ages. Cambridge University Press. 
Holmes, C., \& Standen, N. (2018). Introduction: towards a Global Middle Ages.

Past and Present (2018), Supplement 13

Horden, P., and Smith, R. (1998) The Locus of Care : Families, Communities, Institutions, and the Provision of Welfare Since Antiquity. Routledge

Horden, P. (2019) Cultures of Healing: Medieval and After. Routledge.

Horden, P., \& Hsu, E. (Eds). (2013). The Body in Balance: Humoral Medicines in Practice. Oxford: Berghahn Books.

Jay, M. (2009). Fin de Siècle Socialism and Other Essays (Routledge Revivals). Routledge.

Kaye, J. (2014). A History of Balance, 1250-1375. Cambridge University Press.

Koselleck, R., \& Presner, T. S. (2002). The practice of conceptual history: Timing history, spacing concepts. Stanford University Press.

Kumar, D. (2010). Probing history of medicine and public health in India. Indian Historical Review, 37(2), 259-273.

Kuriyama, S. (1994). The Imagination of Winds and the Development of the Chinese Conception of the Body. In Zito, A,. \& Barlow, T. (Eds). Body, subject, and power in China (pp. 23-41). The University of Chicago Press.

Kuriyama, S. (1999). The expressiveness of the body and the divergence of Greek and Chinese medicine. Zone Books.

Kuriyama, S. (2000). Epidemics, Weather, and Contagion in Traditional Chinese Medicine.

In Conrad, L. I., \& Wujastyk, D. (Eds). Contagion: Perspectives from Pre-Modern Societies (pp. 3-22). Routledge.

Kuriyama, S. (2008). The forgotten fear of excrement. Journal of Medieval and Early Modern Studies, 38(3), 413-442.

Latour, B. (2012) We Have Never Been Modern. Harvard UP

Legg, S. (2007). Beyond the European province: Foucault and postcolonialism. In Elden, S. \& Crampton, J. W. (Eds.). Space, Knowledge and Power: Foucault and Geography (pp. 265-289). Routledge.

Leguay, J. P. (1999). La pollution au Moyen Age: dans le Royaume de France et dans les grands fiefs. Editions Jean-Paul Gisserot.

Leguay, J. P. (2002). L'eau dans la ville au Moyen Âge. PU Rennes. 
To be published in Studies in History and Philosophy of Science (2021), Special Issue, "What counts as environment in biology and medicine: Historical, philosophical and sociological perspectives", Edited by Jan Baedke, Tatjana Buklijas. Pls refer and cite from final version

Lehoux, D. (2012). What did the Romans know?: an inquiry into science and worldmaking. University of Chicago Press.

Lemke, T. (2007). An indigestible meal? Foucault, governmentality and state theory. Distinktion: Scandinavian Journal of Social Theory, 8(2), 43-64.

Lemke, T., Casper, M., \& Moore, L. (2011). Biopolitics: An Advanced Introduction. NYU Press.

Leslie, C. (Ed.). (1998). Asian Medical Systems: A Comparative Study. Vol. 3. Motilal Banarsidass.

Lev, E., \& Amar, Z. (2008). Practical Materia Medica of the Medieval Eastern Mediterranean According to the Cairo Genizah. Brill.

López Beltrán, C. (2007). Hippocratic bodies. Temperament and Castas in Spanish America (1570-1820). Journal of Spanish Cultural Studies, 8(2), 253-289.

Lupton, D. (1995). The Imperative of Health: Public health and the regulated body. Sage.

Maryan, R. (2016). Humoral theory circulating in religious literature in England, c. 13001500 (Doctoral dissertation, University of Nottingham).

Mbembe, A. (2003). Necropolitics. Public culture, 15(1), 11-40.

McVaugh, M. (2002). Medicine before the Plague. Cambridge University Press.

Meloni, M. (2018). A postgenomic body: histories, genealogy, politics. Body \& society, 24(3), 3-38.

Meloni, M. (2019). Impressionable biologies: from the archaeology of plasticity to the sociology of epigenetics. Routledge: New York

Meloni, M. (2021). Porous Bodies: Environmental Biopower and the Politics of Life in Ancient Rome. Theory, Culture \& Society, 38 (3) 91-115

Miglietti, S., \& Morgan, J. (Eds.). (2017). Governing the Environment in the Early Modern World: Theory and Practice. Taylor \& Francis.

Millward, J. A. (2013). The Silk Road: a very short introduction. Oxford University Press.

Nicoud, M. (2016). Les régimes de santé au Moyen Âge. Publications de l'École française de Rome. 
Nutton, V. (2000). “Medical Thoughts on Urban Pollution.” In Valerie M. Hope and Eireann Marshall, eds., Death and Disease in the Ancient City. Routledge, pp. 65-73

Ojakangas, M. (2016). On the Greek origins of biopolitics: A reinterpretation of the history of biopower. Routledge.

Ong, A. (2005). Graduated Sovereignty in South-East Asia. In Inda, J. X. (Ed.). Anthropologies of Modernity. Foucault, Governmentality, and Life Politics (pp. 83104). Oxford: Blackwell

Otabek, M. (2020). The role of the Toledo as a center for the transfer of scientific knowledge of medieval Eastern scientists to Europe. ЕВРАЗИЙСКИЙ СОЮЗ УЧЕНЫХ (ЕСУ), 13.

Petaros, A., Skrobonja, A., Culina, T., Bosnar, A., Frkovic, V., \& Azman, J. (2013). Public Health Problems in the Medieval Statutes of Croatian Adriatic Coastal Towns: From Public Morality to Public Health. Journal of Religion and Health, 52(2), 531-537.

Pezzarossi, G. (2017). “Confites, melcochas y otras golosinas... muy danosas”: sugar, alcohol and biopolitics in colonial Guatemala. In Schwartzkopf, S., \& Sampeck, K. Substance and Seduction Ingested Commodities in Early Modern Mesoamerica (pp. 147-175). University of Texas Press.

Powel, B. (2017). The soldier's tale: Problematising Foucault's military foundations. Review of International Studies, 43(5), pp.833-854

Ramirez, V. (1994). Los antiguos métodos de profilaxis de las enfermedades animales. Anciennes méthodes de prophylaxie des maladies animales. Rev. sci. tech. Off. int. Epiz, 13(2), 343-360.

Raj, K. (2013). Beyond postcolonialism... and postpositivism: Circulation and the global history of science. Isis 104(2): 337-347.

Rawcliffe, C. (2006). Leprosy in Medieval England. Woodbridge, U.K.: Boydell Press.

Rawcliffe, C. (2008). Delectable sightes and fragrant smelles: gardens and health in late medieval and early modern England. Garden History, 36: 3-22.

Rawcliffe, C. (2013). Urban Bodies: communal health in late medieval English towns and cities. Boydell \& Brewer Ltd.

Rawcliffe, C. (2019). The view from the streets: The records of hundred and leet courts as a source for sanitary policing in late medieval English towns. In Rawcliffe, C., \& 
Weeda, C. (Eds), Policing the Urban Environment in Premodern Europe. Amsterdam: Amsterdam University Press.

Redfield, P. (2005). Foucault in the tropics: Displacing the panopticon. In Inda, J. X. (Ed). Anthropologies of modernity: Foucault, governmentality, and life politics (pp. 50-82). John Wiley \& Sons.

Roberts, G. (2019). Police Power in the Italian Communes, 1228-1326. Amsterdam University Press.

Rooney, N. (2020). Ayurveda, Preconception, Biological Plasticity, and the Re-conception of a Nation. Somatosphere: http://somatosphere.net/2020/ayurveda-epigeneticsindia.html/

Rose, N., \& Miller, P. (1992). Political power beyond the state: Problematics of government. British journal of sociology, 173-205.

Rose, N. (2001). The politics of life itself. Theory, culture \& society, 18(6), 1-30.

Rosen, G. (2015). [original 1958] A History of Public Health. Baltimore (MA): JHU Press.

Said, E. (1979). Orientalism. Vintage.

Scheidel, W. I. Morris and R. Saller, eds. (2007), The Cambridge Economic History of the Greco-Roman World. Cambridge: Cambridge University Press

Scott, J. (1998) Seeing like a state: How certain schemes to improve the human condition have failed. Yale University Press, 2020.

Spierenburg, P. (2004). Punishment, power, and history: Foucault and Elias. Social Science History, 28(4), 607-636.

Skelton, L. J. (2015). Sanitation in Urban Britain, 1560-1700. Routledge

Stearns, J. K. (2011). Infectious Ideas: Contagion in Premodern Islamic and Christian Thought in the Western Mediterranean. JHU Press.

Stoler, A. L. (1995). Race and the education of desire: Foucault's history of sexuality and the colonial order of things. Duke University Press.

Syros, V. (2013). Galenic medicine and social stability in early modern Florence and the Islamic empires. Journal of Early Modern History, 17(2), 161-213.

Touati, F. (1998). Maladie et société au Moyen Âge:. Vol. 11. De Boeck Supérieur 
Touati, F. (2000). Contagion and leprosy: myth, ideas and evolution in medieval minds and societies. In Conrad, L. I., \& Wujastyk, D. (Eds). Contagion: Perspectives from PreModern Societies (pp. 179-202). Routledge.

Turner, B. S. (1997). Foreword. In Petersen \& Bunton (Eds.). (1997). Foucault, health and medicine. Psychology Press, IX-XXII

Valérian, D. (2013). Middle East: 7th-15th Centuries. In Clark, P. (ed.) The Oxford Handbook of Cities in World History (pp. 258-274). Oxford: Oxford University Press.

Vanzan Marchini, N. E. (2000). Le leggi di sanità della Repubblica di Venezia, vol. III. Treviso: Neri Pozza.

Varlik, N. (2014). New science and old sources: why the Ottoman experience of plague matters. The Medieval Globe, 1(1), 193-227.

Varlik, N. (2015). Plague and Empire in the Early Modern Mediterranean World. Cambridge University Press.

Veyne, P. (2008). Foucault Sa pensée, sa personne. Albin Michel.

Wey Gómez N (2008) The Tropics of Empire. Why Columbus Sailed South to the Indies. Cambridge: MIT Press.

Weeda, C., \& Rawcliffe, C. (Eds). (2019). Policing the Urban Environment in Premodern Europe. Amsterdam University Press.

Whelan, F. (2017). The Making of Manners and Morals in Twelfth-Century England: The Book of the Civilised Man. Taylor \& Francis.

Wickham, G., \& Goodie, J. A. (2013). Legal and political challenges of governing the environment and climate change: Ruling nature. Routledge.

Yoeli-Tlalim, R. (2019). Galen in Asia?. In Bouras-Vallianatos P, Zipser B (eds) Brill's Companion to the Reception of Galen, (594-608). Brill.

Zimmermann, F. (1988). The jungle and the aroma of meats. Social Science and Medicine 27(3): 197-206.

Zimmerman, F. (1995). The scholar, the wise man, and universals: Three aspects of Āyurvedic medicine. In Bates, D. (Ed). Knowledge and the Scholarly Medical Traditions (pp. 297319). Cambridge University Press. 
To be published in Studies in History and Philosophy of Science (2021), Special Issue, "What counts as environment in biology and medicine: Historical, philosophical and sociological perspectives", Edited by Jan Baedke, Tatjana Buklijas. Pls refer and cite from final version

\footnotetext{
i There are two non-identical versions of Foucault's Politics of Health in the Eighteenth Century. The first published originally in 1976 was then published in English in 1980 in Power/Knowledge (edited and translated by Colin Gordon). The second, originally from 1979, has been published in the journal Foucault studies with the same title 2014. They are distinguished in my text by the year of citation.
}

\begin{abstract}
ii However, while term environment picked up mostly through Spencer as Pearce notes (2010), there are antecedents since the thirteenth century in English where the Middle French word environnement appears. Since the early seventeenth century both environment and circumplexion (in the singular) are used to translate Greek geographers and astronomers to mean the 'action of surrounding something' (Plutarch and Ptolemy for instance): Miglietti and Morgan (2017, Introduction); Wickham and Goodie, (2013, pp. 42-44).
\end{abstract}

iii I observe that Curtis' critique of Foucault's $18^{\text {th }}$ century discovery of 'population,' ultimately tends to produce the same neutralizing effects regarding premodern biopolitics. Curtis introduces a semantic distinction between a supposed premodern notion of populousness and a modern one of population, with this latter only capable to produce "new orders of knowledge, new objects of intervention, new forms of subjectivity and, I argue, new state forms" (2002, p. 507, ,y italics). There is no space to go into the history of the term population here, but I note that Biller (referred also by Curtis) use in his book 'population' to translate the Latin multitudo, not populousness as Curtis writes.

iv The Black Death was of course not the only communicable disease of concern in medieval times: others included dysentery, flu, typhoid, tuberculosis (known as phthisis or consumption) and scrofula (a particularly widespread form of extrapulmonary TB) 